\title{
Sequence Heterogeneity in the Core and NS5A Region of Hepatitis C Virus (HCV) and IL-28B Polymorphisms in Predicting Treatment Response among Chronic HCV Genotype 4 Infected Egyptian Patients
}

\author{
Ghada Fahmy Helaly ${ }^{1}$, Amel Gaber Elsheredy ${ }^{*}$, Essam EI Din Saeed Bedewy ${ }^{2}$ \\ and Nancy Mohamed Attia ${ }^{1}$ \\ ${ }^{1}$ Departments of Microbiology, Medical Research Institute, \\ ${ }^{2}$ Department of Tropical Medicine, Faculty of Medicine, \\ Alexandria University, Alexandria, Egypt \\ *Corresponding author
}

\section{A B S T R A C T}

Keywords

$\mathrm{HCV}$, Core, NS5A, IL28B, SVR.

Article Info

Accepted:

23 June 2017

Available Online:

12 July 2017
Egypt has the highest prevalence of HCV specially genotype 4. Both host and viral factors are important predictors of the efficacy of PEG-IFN/RBV therapy. The aim of this study was to investigate the mutational diversity of $\mathrm{HCV}$ core and NS5A regions and variation of $I L 28 B$ gene to predict virological response. Thirty HCV patients were included in this study. Detection of viral load, amplification and direct sequencing of the core and NS5A genes, determination of IL28B SNPs rs12979860 and rs8099917 polymorphisms were done. Equal percentage $3.3 \%$ of patients were carrying core mutations at position 70 , and 91 , while $6.7 \%$ had mutations at position 71 . The mean number of aa mutations in IRRDR $(8.4 \pm 5.5$ vs. $8.3 \pm 5.8)$ and in ISDR $(6.9 \pm 6.2$ vs. $4.1 \pm 1.8)$. This difference did not reach the statistical significant difference between SVR and non-responders. Regarding IL28B polymorphism for rs $12979860 \mathrm{CC}$ alleles achieved SVR compared to $90.9 \%$ with CT and $50 \%$ with TT alleles; for rs8099917 $66.7 \%$ of patients with either GT or GG genotype achieved SVR. IL28B rs 12979860 polymorphism, severity of fibrosis, and NS5A ISDR $\geq 2$ are useful markers for predicting the outcome of PEG-IFN/RBV therapy.

\section{Introduction}

Hepatitis $\mathrm{C}$ virus (HCV) infection is a major global health problem, considered a major cause of chronic liver diseases. Its ability to evade host defense mechanisms services to establish persistent infection, producing a wide spectrum of pathogenicity (El-Shamy et al., 2014). Based on phylogenetic analysis, $\mathrm{HCV}$ has been classified into seven different genotypes and diverse subtypes (Smith et al., 2014). It is estimated that about 170 million people, $3 \%$ of the world's population, are infected with HCV.
Egypt has the highest prevalence of $\mathrm{HCV}$ worldwide, with an average of $14.7 \%$. HCV genotype 4 (HCV-GT4) is responsible for $90 \%$ of the total HCV infections in Egypt (Lavanchy et al., 2011; Miller et al., 2010).

Pegylated interferon (PEG-IFN) and ribavirin (RBV) are likely to stay the HCV backbone therapy. The addition of direct acting antivirals (DAAs), their combination therapy without IFN and RBV as well as the evolution of resistance-associated variants that may 
attenuate their efficacy do not permit the exclusion of RBV without bargaining rapid and early viral response rates, viral breakthrough, sustained viral response, and relapse rates (Nguyen et al., 2015; Asselah et al., 2008; Suzuki et al., 2012).

In the European Association for the Study of the Liver (EASL) Recommendations on Treatment of Hepatitis C 2015, six treatment options are available in 2015 for patients infected with HCV genotype 4, including two IFN-containing regimens and four IFN-free regimens. In settings where none of these options is available, the combination of PegIFN-a and ribavirin remains acceptable. (EASL Recommendations on Treatment of Hepatitis C, 2015)

Both host and viral genetic factors have been implicated in influencing the clinical response to PEG-IFN/RBV therapy for HCV infection (Kau et al., 2008). Several factors were identified, including age, race, liver fibrosis, $\mathrm{HCV}$ genotype and HCV RNA levels (Shirakawa et al., 2008). Viral factors in the form of genetic heterogeneity in the HCV genome were frequently the focus for investigation of IFN responsiveness, and amino acid substitutions in the core and NS5A regions were reported as markers that could be used to predict the response to IFN therapy. However, these relationships were controversial to clarify IFN responsiveness (El-Shamy et al., 2012; Hayashi et al., 2011; Nakagawa et al., 2010).

Host genetic factors, as well, contribute to IFN treatment outcomes. Therefore, several genome-wide association study (GWAS) were performed to understand the host factors that were associated with IFN responsiveness; such as interleukin-28B (IL28B) gene polymorphisms. The single nucleotide polymorphisms (SNPs) of IL28B, rs12979860 and rs8099917 genotypes are significantly associated with the outcome of IFN therapy (Rauch et al., 2010; Domagalski et al., 2013; Itakura et al., 2015).

The aim of this study was to identify the pretreatment factors including viral (amino acid substitutions in the HCV core gene and NS5A) and host-related factors (genetic variation near the IL28B gene) and the interplay between them that could predict sustained virological response.

\section{Materials and Methods}

\section{Patients}

This study was carried out on thirty HCVinfected treatment-naïve Egyptian patients; of them $24(80 \%)$ males and $6(20 \%)$ females. Their age ranged from 27 to 58 years, they were eligible for combined pegylated interferon and ribavirin therapy Patients with renal, cardiac, neoplasic disease, immunological disorders and cirrhotic patients as well as patients with $\mathrm{HBV}$ and HIV co-infection were excluded from the study. Baseline characteristics of the patients involved were illustrated in table 1. Liver biopsy was performed for each patient. Grading and staging for activity and fibrosis was done according to the METAVIR criteria. Patients received subcutaneous injections of pegylated- IFN-a $2 \mathrm{~b}(1.5 \mathrm{mg} / \mathrm{kg})$ once each week plus oral ribavirin (1000-1200 mg/day) daily. The study was approved by the Institutional Ethics Committee. Written informed consent was obtained from each patient prior to enrollment in the study.

Blood samples $(5 \mathrm{ml})$ were collected from each patient, and divided into $3 \mathrm{ml}$ in plain tubes for some biochemical investigations and molecular investigations as pretreatment detection of HCV-RNA viral load by Real Time PCR. And $2 \mathrm{ml}$ in $0.5 \mathrm{M}$ EDTA tubes for determination of IL28B SNPs rs12979860 
and rs8099917 polymorphisms by Real Time PCR.

Sequence analysis of hepatitis $C$ virus NS5A and the core regions of the hepatitis $\mathrm{C}$ virus genome

Viral RNA was extracted from patients' sera using QIAamp viral RNA mini spin Kit (Qiagen ${ }^{\circledR}$ ) according to manufacturer's instructions.

The extracted viral RNA was used as a template for viral load determination by real time PCR using Artus HCV QS-RGQ-PCR Kit (Qiagen $\left.{ }^{\circledR}\right)$.

Transcription of RNA into cDNA was done using RevertAid First Strand cDNA Synthesis Kit (Thermo Scientific) with random hexamers. RT was performed at $25^{\circ} \mathrm{C}$ for 5 min followed by $60 \mathrm{~min}$ at $42^{\circ} \mathrm{C}$ and then terminated by heating at $70^{\circ} \mathrm{C}$ for 5 minutes.

Amplification of NS5A and the core regions of the HCV genome were performed. Primers used for amplification of the NS5A region of HCV were as follows: NS5A/F1 (5'CTCAAYTCGTTCGTRGTGGGATC-3'; sense) and NS5A/R1 (5'-CGAAGGTC ACCTTCTTCTGCCG-3'; antisense) for onestep RT-PCR; and NS5A/F2 (5'-ATGCGA GCCYGAGCCGGACGT-3'; sense) and NS5A/R2 (5'-GCTCAGGGGGYT RATTG GCAGCT-3'; antisense) for the second-round PCR. Primers used for amplification of the core region of HCV were core/F1 (5'GCTAGCCGAGTAGTGTTG-3'; sense) and core/R1 (5'-GATGTGRTGRTCGGCCTC-3'; antisense) for one-step RT-PCR; and core/F2 (5'-GGAGGTCTCGTAGACCGTGC-3'; sense) and core/R2 (5'-ATGTACCCCA TGAGGTCGGC-3'; antisense) for the second-round PCR.

For the amplification of NS5A and the core regions, nested PCR was used. The first run amplification was performed in $50 \mu \mathrm{L}$ final reaction volume containing $2 \mathrm{X}$ DreamTaq Green PCR Master Mix (Thermo Scientific), 5 picomoles of each of the outer primers and $2 \mu \mathrm{L}$ of copy DNA. The thermal cycling consisted of one cycle of initial denaturation at $95^{\circ} \mathrm{C}$ for 5 minutes followed by 35 cycles of denaturation at $95^{\circ} \mathrm{C}$ for 30 seconds, annealing step at $50^{\circ} \mathrm{C}$ for 30 seconds, and extension step at $72^{\circ} \mathrm{C}$ for 60 seconds, each with a final extension cycle at $72^{\circ} \mathrm{C}$ for 10 minutes. The second-round PCR was performed under the same conditions as the first run.

The purified NS5A and core PCR products were sequenced using the BigDye Terminator V 3.1 Cycle Sequencing Kit (Applied Biosystems) and the automated sequencer ABI prism 310 genetic analyzer (Applied Biosystems).

For determination of $\mathrm{HCV}$ genotypes and subtypes, NS5A and the core sequencing results was analyzed using HCV BLAST free online tool from $\mathrm{HCV}$ sequence database

Bio Edit Sequence alignment editor version 7.2.5 and ClustalW multiple alignment tool were used to undergo align NS5A and core Nucleotide and amino acid sequences from different patient isolates in order to determine the presence of mutations (Figs. 2, 4 and 5).

\section{SNP genotyping}

The two IL28B SNPs rs12979860 and rs8099917 were genotyped for each patient. Genomic DNA was extracted from peripheral blood samples $(2 \mathrm{ml})$ collected in $0.5 \mathrm{M}$ EDTA tubes of all patients using PureLink ${ }^{\mathrm{TM}}$ Genomic DNA Mini Kit (Invitrogen) according to the manufacturer's protocol. Polymorphisms rs12979860 (C > T) and rs8099917 ( $\mathrm{T}>\mathrm{G}$ ) in gene IL28B were genotyped by Real-Time PCR, TaqMan realtime allelic discrimination assay using a Step 
One PLUS Sequence Detector (Applied Biosystems, Foster City, CA, USA), $2 \mu$ I DNA was used for PCR with primers and probes from a commercial kit (Taqman SNP Genotyping Assays, Applied Biosystems).

\section{Statistical analysis}

Data were collected, coded and fed to statistical software SPSS version 20. The given graphs were constructed using Microsoft excel software.

Means and Standard deviations were estimated for quantitative data. For correlations, Spearman correlation coefficient was applied. Groups were compared by independent samples t-test, Mont Carlo exact probability or Mann-Whitney $U$ test as appropriate. $\mathrm{P}$ value $\leq 0.05$ was considered to be significant.

To evaluate the optimal threshold of the number of amino acid mutations in ISDR and IRRDR for prediction of treatment outcomes, the receiver operating characteristic (ROC) curve was constructed. Multiple stepwise logistic regression analysis was performed to identify variables that independently predicted the treatment outcome.

\section{Results and Discussion}

Out of the $30 \mathrm{HCV}$ patients included in this study, 20 patients $(66.7 \%)$ showed sustained viral response (SVR), while 10 patients (33.3\%) were non-responders.

The relation between viral load and SVR was illustrated in table 2.

Twenty-three (76.7\%) of the studied cases had liver biopsy showing established fibrosis (F2, F3) before starting treatment according to METAVIR scoring system, while $23.3 \%$ (7/30) have minimal fibrosis. Out of the 7 cases with minimal fibrosis, 5 (71.4\%) have SVR to antiviral treatment, on the other hand, $65.2 \%(15 / 23)$ of those with established fibrosis display SVR (Table 3).

Regarding the distribution of core mutations among the 30 patients was shown in table 4 . Patients carried core mutations at position 70 , and 91 did not respond to treatment, while the 2 cases carried mutations at position 71 responded to treatment.

The mean number of aa mutations within IRRDR, ISDR of HCV NS5A obtained from pretreatment sera of $27 \mathrm{HCV}$ GT-4-infected patients with SVR and non-responders (NS5A was not amplified in 3 cases) was calculated. The mean number of aa mutations in IRRDR $(\mathrm{SVR}=8.4 \pm 5.5$ vs. Non-responders $=8.3 \pm$ 5.8; $\mathrm{p}=0.995)$, however, no significant difference was observed between SVR and non-responders. The mean number of aa mutations in ISDR $(6.9 \pm 6.2$ vs. $4.1 \pm 1.8 ; \mathrm{p}$ $\left.={ }^{\mathrm{U}} \mathrm{p}=0.118\right)$; this difference did not reach the statistical significance (Fig. 1B, 3, 4, 5)

On performing ROC curve analysis to estimate the optimal cutoff number of ISDR and IRRDR mutations for SVR prediction. The analysis estimated 2 mutations for ISDR and 5 mutations for IRRDR as the optimal number to predict SVR (Fig. 3A, B). 83.3\% of patients with SVR had HCV with ISDR mutations of $\geq 2$. In contrast, $66.7 \%$ of the patients with non-responders had ISDR mutations $<2(P=0.048)$.

On the other hand, the sequence heterogeneity within IRRDR is closely associated with the SVR in Egyptian patients infected with HCV GT-4 with a high degree of sequence variation in IRRDR, i.e., (IRRDR $\geq 5$ ) $(P=0.086)$, while a low degree of sequence variation in this region (IRRDR $<5$ ) had no effect on treatment outcome (Fig. 3C, D). 


\section{IL-28B polymorphism (rs12979860 and rs8099917 alleles)}

For rs 12979860 alleles, $18 / 30$ cases $(60 \%)$ of the studied cases possess TT alleles, while CT alleles were found in $11 / 30$ cases $(36.7 \%)$ and $\mathrm{CC}$ allele profile was only found in 1 case (3.3\%). For rs8099917 alleles, no case displays TT alleles, on the other hand, GG and TG represented by 60 and $40 \%$, respectively. Regarding relation between rs12979860 and response to treatment, the case with $\mathrm{CC}$ alleles was viral responder compared to $90.9 \%$ with $\mathrm{CT}$ and $50 \%$ with TT alleles; these differences were found to be statistically significant. On the other hand, for rs8099917, TT genotype was not displayed, and $66.7 \%$ of patients with either GT or GG alleles were achieved SVR (Table 5).

The case having CC alleles for $I L-28 B$ SNP (rs12979860) was found to have no core mutations compared to $90.9 \%$ of cases having $\mathrm{CT}$ alleles. Interestingly, the $\mathrm{HCV}$ cases carrying core mutations at position 70 , and 91, having TT alleles, similarly, In case of $I L$ $28 B$ SNP (rs8099917), it was found also that the $\mathrm{HCV}$ cases carrying core mutations at position 70 , and 91 , having GG alleles. However, these differences did not reach statistical significance.

The identification of independent predictive factors for SVR by multivariate logistic regression analysis revealed that alpha fetoprotein (AFP), IL-28Brs1297986060, Liver biopsy, and NS5A ISDR were correlated with the treatment outcome; representing independent predictive factors of PEG-IFN/RBV treatment outcome (Table 6).

$\mathrm{HCV}$ infection is a major global health problem, considered a major cause of chronic liver disease, HCC, and deaths from liver disease and is the most common indication for liver transplantation. PEG-IFN/RBV combination therapy is standard treatment for patients with chronic hepatitis $\mathrm{C}$. The addition of DAA, their combination therapy without IFN and RBV and resistance developed does not permit the exclusion of RBV without compromising RVR and SVR rates, viral breakthrough, and relapse rates (Asselah et al., 2011; Fusco et al., 2011; Bronowicki et al., 2012).

Both host and viral genetic factors have been implicated in influencing the clinical response to PEG-IFN/RBV therapy for HCV infection (Kau et al., 2008). The aim of this study was to identify the pretreatment factors that could predict sustained virological response, including viral (aa substitutions in the hepatitis C virus core gene and NS5A) and host-related factors (genetic variation near the IL28B gene).

The present study included $30 \mathrm{HCV}$ naïve patients, $24(80 \%)$ were males and $6(20 \%)$ were females. Their age ranged from 27 to 58 years, with the highest percentage $(50 \%)$ of the patients were in the age range between 40$<50$ years. Our results are consistent with previous studies reporting higher prevalence of $\mathrm{HCV}$ in age groups older than 30 years. Darwish et al., 1992 reported that anti-HCV among those 20 to 30 years old was $6 \%$, as compared with $37.5 \%$ among those older than 30 years.

Genotype identification is clinically important for prediction of responses to, and in determining the duration of, antiviral therapy (Zein et al., 1996). HCV genotype 4 has the highest prevalence among Egyptians, with a predominance of the subtype $4 \mathrm{a}(\mathrm{HCV}-4 \mathrm{a})$ (Lavanchy et al., 2011; Miller et al., 2010).

Sequencing and phylogenetic analysis of the core/E1 or NS5B region were considered to be the gold standard for HCV genotyping since they accurately identified the subtype 
(Cai et al., 2013). In the present study, core sequence analysis was evaluated for its effectiveness in identifying $\mathrm{HCV}$ genotypes/subtypes in the studied Egyptian patients. All the 30 isolates were successfully genotyped and sub-genotyped; 27 patients (90\%) of them were of sub-genotype $4 \mathrm{a}$, while the remaining 3 cases $(3.3 \%)$ were equally distributed within $4 \mathrm{n}, 4 \mathrm{o}, 41$ genotypes.

In the present work, $76.7 \%$ of the $\mathrm{HCV}$ patients had liver biopsy showing established fibrosis before starting treatment, while 23.3\% have minimal fibrosis. With logistic regression analysis, state of liver injury was among the predicting factors of SVR In agreement with our results, Powis et al., (2008) in their study on chronic HCV infections with GT-3 exploring a significant poor antiviral response in such patients with advanced liver injury.
In the present study, $63.3 \%$ had a viral load ranging between $10^{5}$ and $10^{7} \mathrm{IU} / \mathrm{ml}$; viral load was associated with SVR since $52.6 \%$ with viral load above $10^{5} \mathrm{IU} / \mathrm{ml}$ achieved SVR compared to $90.9 \%$ of patients with viral load $<10^{5} \mathrm{IU} / \mathrm{ml}$. Our results agreed with Magrin et al., (1996) who found in his study that low pre-treatment serum HCV-RNA level, was important predictor of response to IFN therapy. On the other hand, Fallows et al., 2000 found that pre-treatment viral load did not affect the outcome of treatment.

The difference in responses among patients infected with different HCV genotypes suggests that viral genetic heterogeneity could affect, at least to some extent, the sensitivity to IFN-based therapy. In this context, the correlation between IFN-based therapy outcome and sequence polymorphisms within the viral core and NS5A proteins has been investigated.

Table.1 Baseline characteristics of the HCV patients $(n=30)$ according to gender

\begin{tabular}{|c|c|c|c|c|c|c|c|}
\hline \multirow{3}{*}{ Parameter } & \multirow{2}{*}{\multicolumn{2}{|c|}{ Total }} & \multicolumn{4}{|c|}{ Gender } & \multirow{3}{*}{$\mathbf{t}(\mathbf{P})$} \\
\hline & & & \multicolumn{2}{|c|}{ Male (24) } & \multicolumn{2}{|c|}{ Female (6) } & \\
\hline & Mean & \pm SD & Mean & \pm SD & Mean & \pm SD & \\
\hline Age (Years) & 43.8 & \pm 10.3 & 42.3 & \pm 10.6 & 50.0 & \pm 6.6 & $1.6(0.103)$ \\
\hline BMI & 26.8 & \pm 2.1 & 26.7 & \pm 2.2 & 27.2 & \pm 1.8 & $0.49(0.627)$ \\
\hline Glucose & 91.1 & \pm 15.3 & 93.4 & \pm 15.8 & 81.7 & \pm 8.6 & $1.7(0.092)$ \\
\hline Creatinine & 0.8 & \pm 0.2 & 0.8 & \pm 0.2 & 0.7 & \pm 0.2 & $1.4(0.163)$ \\
\hline Albumin & 4.4 & \pm 0.9 & 4.2 & \pm 0.5 & 5.0 & \pm 1.8 & $1.0(0.353)$ \\
\hline Alkaline phosphatase & 77.2 & \pm 34.3 & 77.6 & \pm 31.9 & 75.7 & \pm 46.1 & $0.12(0.903)$ \\
\hline AST & 15.0 & \pm 9.2 & 15.6 & \pm 10.1 & 12.8 & \pm 4.0 & $0.65(0.524)$ \\
\hline ALT & 18.1 & \pm 12.3 & 19.3 & \pm 13.3 & 13.3 & \pm 6.0 & $1.1(0.294)$ \\
\hline T.Bilirubin & 0.8 & \pm 0.2 & 0.8 & \pm 0.2 & 0.8 & \pm 0.1 & $0.31(0.760)$ \\
\hline WBC $* 10^{3}$ & 6.2 & \pm 1.7 & 6.3 & \pm 1.8 & 6.0 & \pm 1.2 & $0.33(0.737)$ \\
\hline $\mathrm{Hb}$ & 13.9 & \pm 1.2 & 14.3 & \pm 1.1 & 12.4 & \pm 0.3 & $8.0(0.001)^{*}$ \\
\hline Platelets* $10^{3}$ & 203.6 & \pm 73.6 & 178.9 & \pm 41.5 & 302.5 & \pm 94.2 & $3.1(0.023)^{*}$ \\
\hline Prothrombin & 94.4 & \pm 7.1 & 94.2 & \pm 7.4 & 95.2 & \pm 6.3 & $0.30(0.763)$ \\
\hline ANA titer & 3.7 & \pm 6.1 & 3.3 & \pm 5.7 & 5.7 & \pm 8.5 & $0.63(0.452)$ \\
\hline TSH & 1.9 & \pm 1.3 & 1.9 & \pm 0.9 & 2.3 & \pm 2.5 & $0.39(0.706)$ \\
\hline AFP & 3.5 & \pm 2.0 & 3.8 & \pm 2.1 & 2.5 & \pm 1.6 & $1.4(0.168)$ \\
\hline ANC & 2436.8 & \pm 541.3 & 2511.7 & \pm 564.8 & 2100.0 & \pm 241.5 & $1.4(0.175)$ \\
\hline
\end{tabular}

t: independent samples t-test; $*$ P < 0.05 (significant); Values are mean \pm standard deviation (SD);

BMI body mass index, ALT alanine aminotransferase, AST aspartate aminotransferase 
Table.2 Viral load in relation to sustained virological response among the studied cases

\begin{tabular}{|c|c|c|c|c|c|c|}
\hline \multirow[t]{2}{*}{ Viral load(IU/ml) } & \multicolumn{2}{|c|}{ SVR } & \multicolumn{2}{|c|}{$\begin{array}{c}\text { Non- } \\
\text { responders }\end{array}$} & \multirow[t]{2}{*}{ Total } & \multirow[t]{2}{*}{$M C P$} \\
\hline & No & $\%$ & No & $\%$ & & \\
\hline$>10^{2} \leq 10^{3}$ & 2 & 100.0 & 0 & 0.0 & 2 & \multirow{7}{*}{$0.007 *$} \\
\hline$>10^{3} \leq 10^{4}$ & 2 & 100.0 & 0 & 0.0 & 2 & \\
\hline$>10^{4} \leq 10^{5}$ & 6 & 85.7 & 1 & 14.3 & 7 & \\
\hline$>10^{5} \leq 10^{6}$ & 8 & 80.0 & 2 & 20.0 & 10 & \\
\hline$>10^{6} \leq 10^{7}$ & 0 & 0.0 & 6 & 100.0 & 6 & \\
\hline$>10^{7}$ & 2 & 66.7 & 1 & 33.3 & 3 & \\
\hline Total & \multicolumn{2}{|c|}{20} & \multicolumn{2}{|c|}{10} & 30 & \\
\hline
\end{tabular}

MCP: Mont Carlo exact probability * $\mathrm{P}<0.05$ (significant)

Table.3 Distribution of the $30 \mathrm{HCV}$ cases considering their response to Treatment in relation to liver biopsy (METAVIR score)

\begin{tabular}{|c|c|c|c|c|c|c|}
\hline \multirow{3}{*}{ Liver Biopsy } & \multicolumn{4}{|c|}{ Response } & \multirow{2}{*}{\multicolumn{2}{|c|}{$\begin{array}{c}\text { Total } \\
(\mathbf{n}=\mathbf{3 0})\end{array}$}} \\
\hline & \multicolumn{2}{|c|}{ Non responder $(n=10)$} & \multicolumn{2}{|c|}{ Responder $[\operatorname{SVR}](\mathrm{n}=\mathbf{2 0})$} & & \\
\hline & No & $\%$ & No & $\%$ & No & $\%$ \\
\hline A1F1 & 2 & 50.0 & 2 & 50.0 & 4 & 13.3 \\
\hline A1F2 & 2 & 100.0 & 0 & 0.0 & 2 & 6.7 \\
\hline A2F1 & 0 & 0.0 & 3 & 100.0 & 3 & 10.0 \\
\hline A2F2 & 5 & 26.3 & 14 & 73.7 & 19 & 63.3 \\
\hline A2F3 & 1 & 50.0 & 1 & 50.0 & 2 & 6.7 \\
\hline
\end{tabular}

F1: portal and periportal fibrosis with no septum, F2: portal and periportal fibrosis with rare septum, F3: portal and periportal fibrosis with many septum, A1: minimal necroinflammatory activity, A2: moderate necroinflammatory activity

Table.4 Distribution of Core mutations among the studied cases and

The irrelation to response to treatment

\begin{tabular}{|c|c|c|c|c|c|c|}
\hline \multirow[t]{3}{*}{ HCV mutation } & \multicolumn{4}{|c|}{ Response } & \multirow[t]{4}{*}{ Total } & \multirow[t]{3}{*}{$M C P$} \\
\hline & \multicolumn{2}{|c|}{ Non responder } & \multicolumn{2}{|c|}{ Responder } & & \\
\hline & No & $\%$ & No & $\%$ & & \\
\hline \multicolumn{5}{|l|}{ Core mutation } & & \multirow[t]{5}{*}{0.166} \\
\hline - $\quad$ Non / other mutations & 8 & 30.8 & 18 & 69.2 & 26 & \\
\hline 70 & 1 & 100.0 & 0 & 0.0 & 1 & \\
\hline 71 & 0 & 0.0 & 2 & 100.0 & 2 & \\
\hline 91 & 1 & 100.0 & 0 & 0.0 & 1 & \\
\hline
\end{tabular}

MCP: P value based on Mont Carlo exact probability 
Table.5 Relation of IL $28 B$ polymorphism to response to treatment

\begin{tabular}{|c|c|c|c|c|c|c|}
\hline \multirow{3}{*}{ IL 28B SNP } & \multicolumn{4}{|c|}{ Response } & \multirow{3}{*}{ Total } & \multirow{3}{*}{$M C P$} \\
\hline & \multicolumn{2}{|c|}{ Non- responder } & \multicolumn{2}{|c|}{ SVR } & & \\
\hline & No & $\%$ & No & $\%$ & & \\
\hline \multicolumn{6}{|l|}{ rs12979860 } & \multirow{4}{*}{$0.050 *$} \\
\hline - $\quad \mathrm{CC}$ & 0 & 0.0 & 1 & 100.0 & 1 & \\
\hline $\mathrm{CT}$ & 1 & 9.1 & 10 & 90.9 & 11 & \\
\hline $\mathrm{TT}$ & 9 & 50.0 & 9 & 50.0 & 18 & \\
\hline \multicolumn{6}{|l|}{ rs8099917 } & \multirow{3}{*}{1.000} \\
\hline GG & 6 & 33.3 & 12 & 66.7 & 18 & \\
\hline TG & 4 & 33.3 & 8 & 66.7 & 12 & \\
\hline
\end{tabular}

MCP: P value based on Mont Carlo exact probability, $* \mathrm{P}<0.05$ (significant)

Table.6 Multiple stepwise logistic regression analysis for predictors of response to Treatment with PEG-IFN/RBV for thirty HCV infected naive patients

\begin{tabular}{|l|c|c|c|c|c|c|}
\hline \multirow{2}{*}{ Variables } & \multirow{2}{*}{ B } & \multirow{2}{*}{ S.E. } & \multirow{2}{*}{ Sig. } & \multirow{2}{*}{$\operatorname{Exp~(B)~}$} & \multicolumn{2}{|c|}{ 95.0\% C. I. for Exp (B) } \\
\cline { 5 - 7 } & & & & & Lower & Upper \\
\hline AFP & -.877 & .361 & $\mathbf{. 0 1 5}$ & $\mathbf{. 4 1 6}$ & .205 & .844 \\
\hline rs1297986060 & -1.928 & .256 & $\mathbf{. 0 4 7}$ & $\mathbf{. 1 4 5}$ & .070 & .452 \\
\hline Liver biopsy(fibrosis) & -.007 & .224 & $\mathbf{. 0 4 4}$ & $\mathbf{. 8 5 0}$ & .375 & .980 \\
\hline NS5A(ISDR) & .301 & .102 & $\mathbf{. 0 4 6}$ & $\mathbf{1 . 3 5 1}$ & 1.114 & 2.037 \\
\hline
\end{tabular}

Fig.1 PCR products of core gene and NS5A genes: A) PCR products (core gene) were analyzed on a $2 \%$ agarose gel stained with ethidium bromide, compared to a $100 \mathrm{bp}$ DNA ladder and visualized by ultraviolet light showing a band of $573 \mathrm{bp}$ length. B) PCR products (NS5A gene) were analyzed on a $2 \%$ agarose gel stained with ethidium bromide, compared to a $100 \mathrm{bp}$ DNA ladder and visualized by ultraviolet light showing a band of $675 \mathrm{bp}$ length

A.

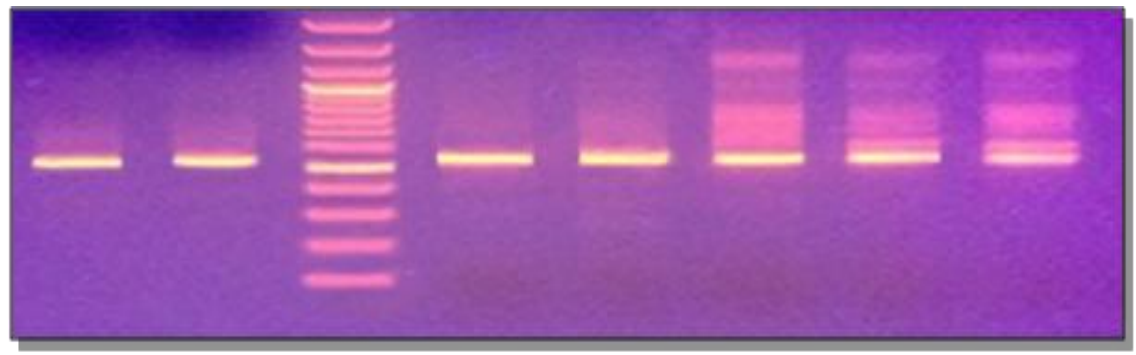

B.

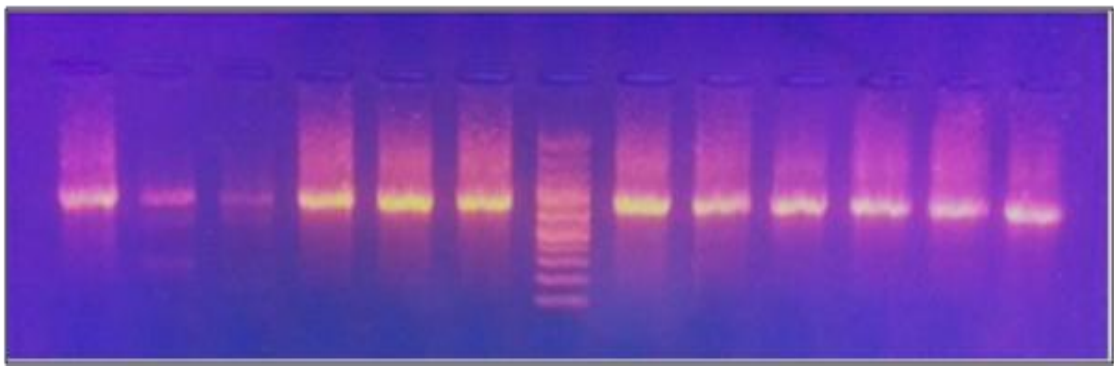


Fig.2 Amino acid sequence alignment in the core region obtained from sera of the 30 HCV GT-4 cases showing amino acid substitutions at positions 70, 71 and 91 in the Core region. Amino acid sequences were aligned with Bio Edit.

Reference Sequence with accession number (DQ988078) is shown at the top

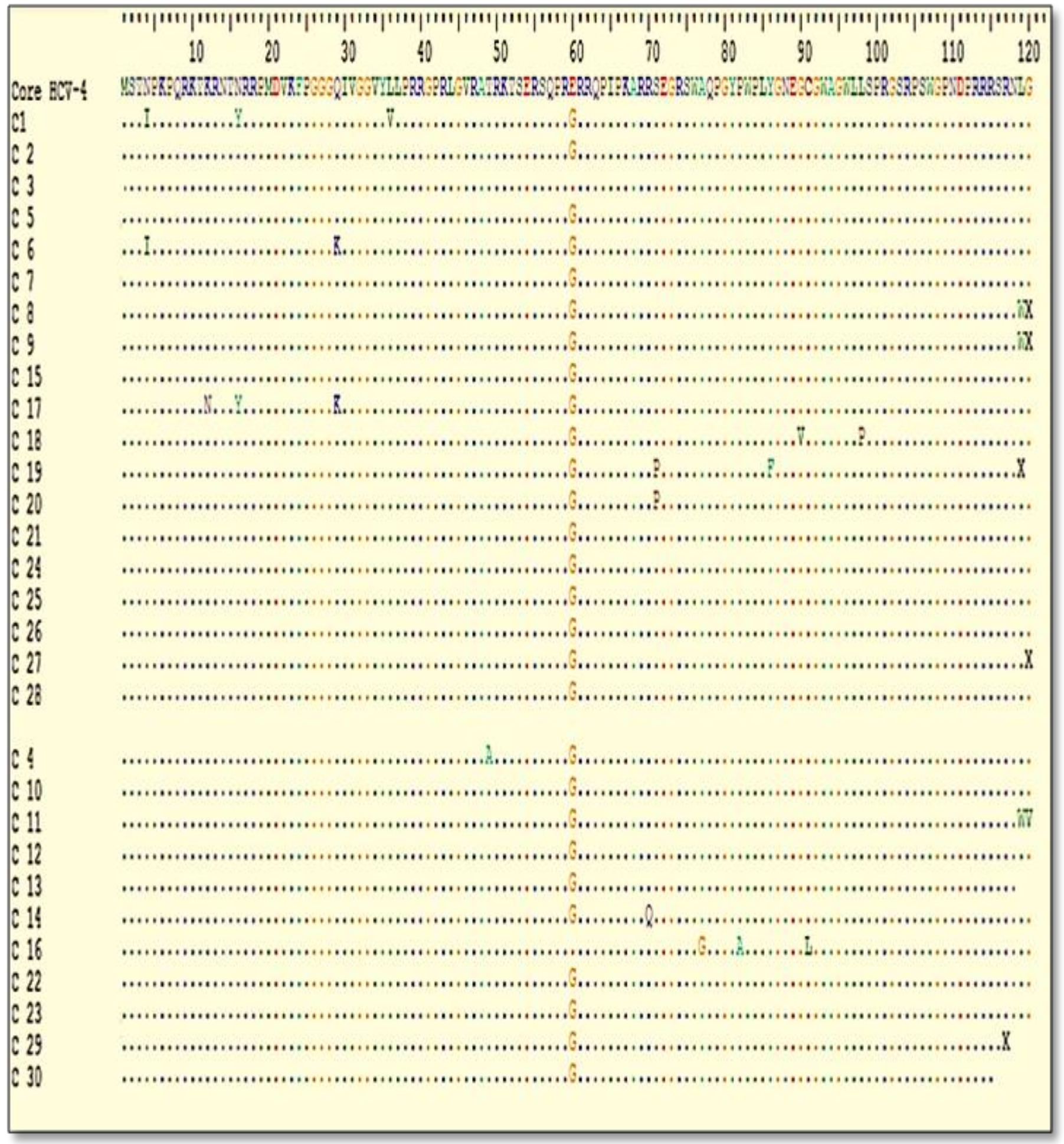


Fig.3 A) ROC curve analysis of NS5A ISDR [HCV GT-4] sequence heterogeneity for SVR prediction. The solid blue line curve shows the AUC. The optimal number of ISDR [HCV GT-4] mutations for SVR prediction, which yields the highest sensitivity (75\%) and the highest specificity (75\%) was 2.00. B) ROC curve analysis of NS5A IRRDR [HCV GT-4] sequence heterogeneity for SVR prediction. The solid blue line curve shows the AUC. The optimal number of IRRDR [HCV GT-4] mutations for SVR prediction, which yields the highest sensitivity (80\%) and the highest specificity (70\%) was 5.00. C) Sustained virologic response among 27 studied patients according to the optimal number of ISDR [HCV GT-4] mutations. D)

Sustained virologic response among 27 studied patients according to the optimal number of IRRDR [HCV GT-4] mutations
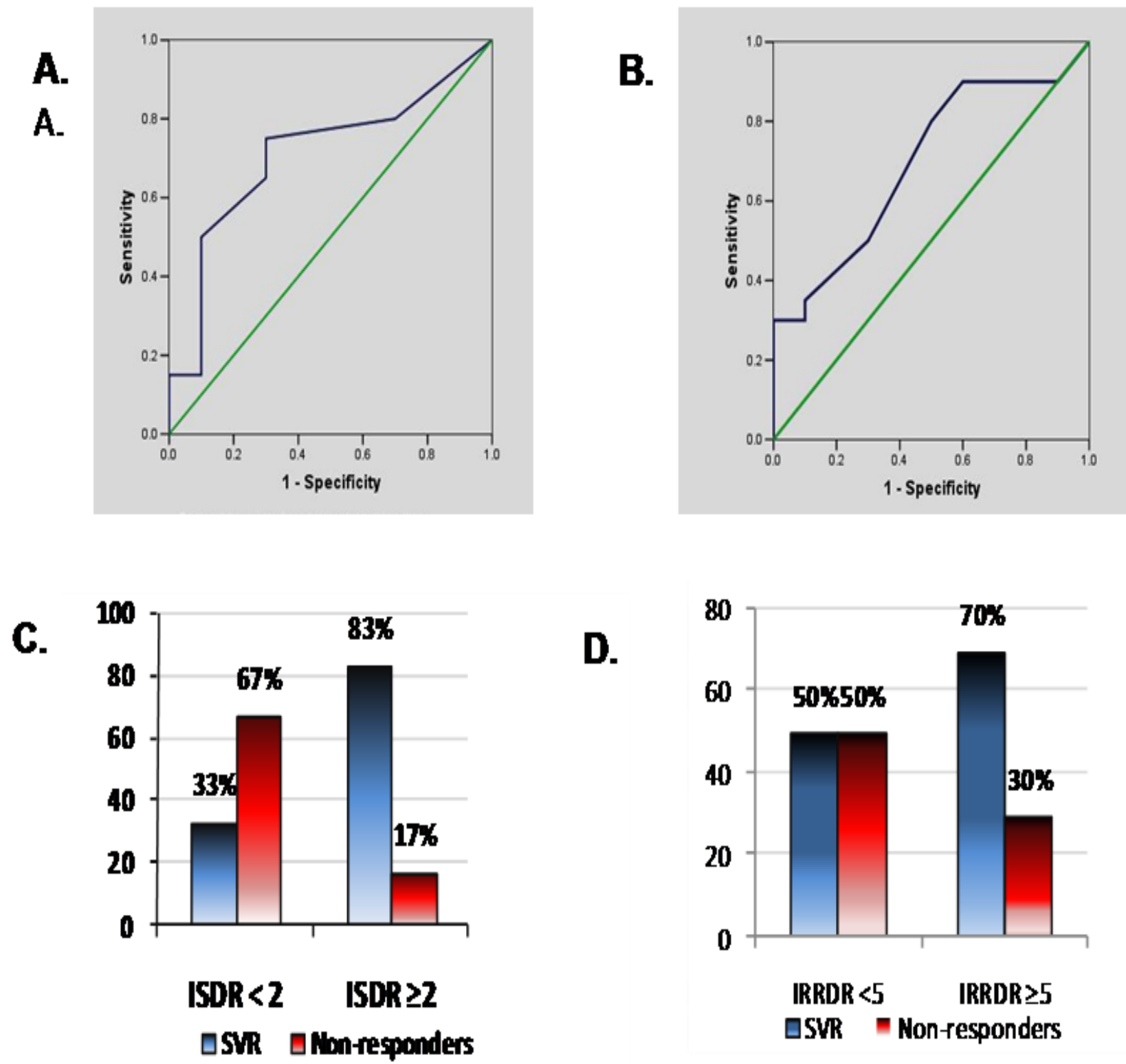

SVR; Sustained virologic response, ISDR; Interferon sensitivity-determining region., IRRDR; Interferon sensitivitydetermining region 
Fig.4 Bio Edit amino acid sequence alignment in the NS5A ISDR region showing amino acid substitutions in the NS5A ISDR region of the 27 HCV GT-4 cases.

Reference Sequence with accession number (DQ988078) is shown at the top

\begin{tabular}{|c|c|}
\hline $\begin{array}{l}\text { ISDR HCV-4 } \\
\text { A } 1 \\
\text { A } 2 \\
\text { A } 3 \\
\text { A } 6 \\
\text { A } 7 \\
\text { A } 8 \\
\text { A } 9 \\
\text { A } 15 \\
\text { A } 17 \\
\text { A } 18 \\
\text { A } 19 \\
\text { A } 20 \\
\text { A } 24 \\
\text { A } 25 \\
\text { A } 26 \\
\text { A } 27 \\
\text { A } 28\end{array}$ & 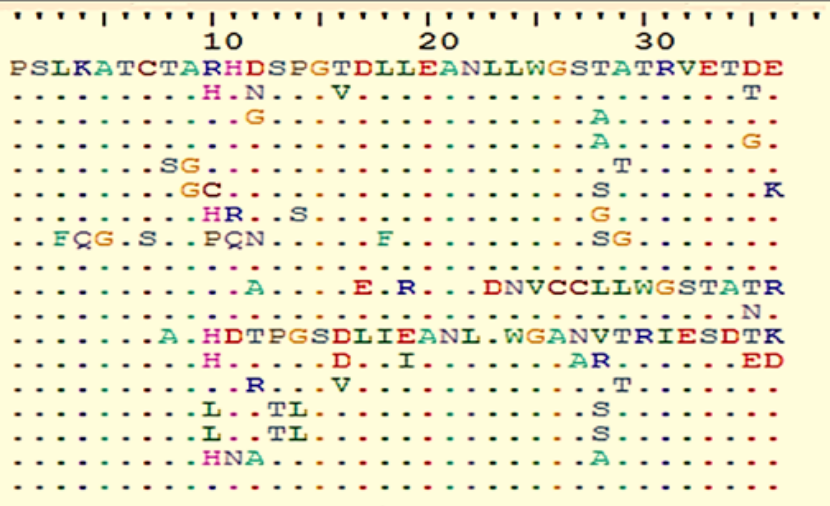 \\
\hline $\begin{array}{ll}\text { A } & 4 \\
\text { A } & 10 \\
\text { A } & 11 \\
\text { A } & 13 \\
\text { A } & 14 \\
\text { A } & 16 \\
\text { A } & 22 \\
\text { A } & 23 \\
\text { A } & 29 \\
\text { A } & 30\end{array}$ & - \\
\hline
\end{tabular}

Fig.5 Bio Edit amino acid sequence alignment in the NS5A IRRDR region showing amino acid substitutions in the NS5A IRRDR region of the 27 HCV GT-4 cases Reference Sequence with accession number (DQ988078) is shown at the top

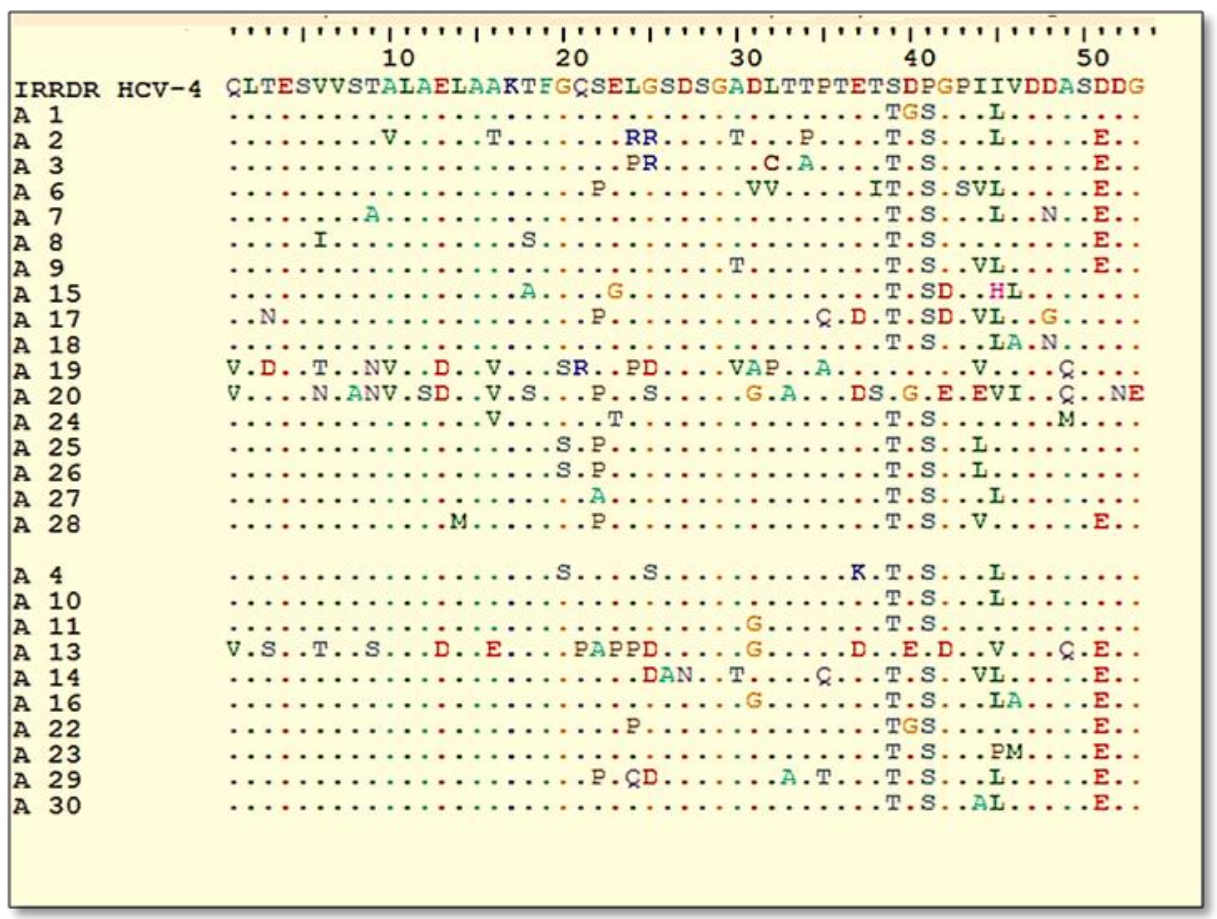


HCV NS5A and core protein polymorphisms in particular at positions 70 and 91, was proposed as a pretreatment predictor of poor virological response. Minimal researches handled information regarding the correlation between sequence heterogeneity in the NS5A and core proteins of HCV GT-4 and PEGIFN/RBV treatment outcome. Therefore, in the present study, we aimed to probe this concern in Egyptian patients infected with HCV GT-4.

As regards core variability as the residues at positions 70 and 91 were both well conserved among the sequences analyzed, and as there are only two cases one for each mutation 70 and 91, no evident correlation with treatment outcome was observed for these residues. On the other hand, Pro at position 71 showed a tendency to be more frequent in SVR than in non-responders. Compared to our results, ElShamy et al., (2012) found no significant correlation between core gene polymorphism and treatment outcome in HCV GT-4 infection. In concordance with our study, the residue at position 70 of the core protein of all but two HCV GT-4 isolates analyzed in their study was Arg. They concluded that, this high degree of sequence conservation at position 70 might be the reason for the lack of significant correlation between core protein polymorphism and treatment outcome in HCV-GT4 infection. Previous studies (Hayashi et al., 2011; Okanoue et al., 2009) carried out on genotype 1b HCV infection, showed that the mutations in aa 70 and 91 in the core region correlated with SVR during PEG-IFN/RBV combination treatment. Conversely, Enomoto et al., 2010 reported that core 70Q substitution was not associated with SVR.

Viral genetic polymorphisms, in the NS5A especially (ISDR and IRRDR) regions, among $\mathrm{HCV}$ isolates have been linked to the difference in SVR rates to PEG-IFN/RBV therapy (El-Shamy et al., 2012; Okanoue et al., 2009).

In the present study the sequence heterogeneity within ISDR was closely associated with the SVR in the studied patients. A sequence variation of $\geq 2$ significantly correlated with SVR. The majority of patients with SVR $(83.3 \%)$ had $\mathrm{HCV}$ with ISDR of $\geq 2$. In contrast, two-thirds $(66.7 \%)$ of the non-responders had HCV with ISDR $<2(P=0.048)$. Our present results suggest that the degree of sequence heterogeneity within ISDR would be an independent marker for prediction of SVR in HCV GT-4 infection.

The number of mutations in the ISDR was shown to be associated with the viral response to PEG-IFN/RBV combination treatment in Japan (Hayashi et al., 2011; Nakagawa et al., 2010). On the other hand, Enomoto et al., 2010 reported that mutations in NS5A ISDR are associated with no SVR during PEGIFN/RBV combination therapy.

Our result was coincident with previous studies (Hayashi et al., 2011; 31.El-Shamy et al., 2011) reporting that the original criterion of ISDR $\geq 4$ to predict SVR was substituted by ISDR $\geq 2$. This might result from the selective impact of IFN monotherapy, whereby the prevalence of sensitive isolates with ISDR $\geq 4$ was decreased while that of $\mathrm{HCV}$ isolates of ISDR $\leq 3$ was increased.

The molecular mechanism of ISDR-mediated IFN resistance is still unclear. Some studies have revealed that NS5A binds to and suppresses the function of the IFN induced PKR. PKR is known to inhibit viral replication by inhibiting viral protein synthesis through phosphorylation of eIF-2 (Gale et al., 1998). It has also been demonstrated in vitro that NS5A induces the expression of IL-8 at both the mRNA and 
protein levels. IL-8 is known to inhibit IFN- $\alpha$ signaling pathway (Polyak et al., 2001).

In the present study the sequence heterogeneity within IRRDR was closely associated with the SVR in patients with a high degree of sequence variation in IRRDR (IRRDR $\geq 5$ ), while a low degree of sequence variation in this region (IRRDR <5) had no effect on treatment outcome. However, with logistic regression analysis in our study, IRRDR was not among the predicting factors of SVR.

Previously, IRRDR $\geq 6$ was identified as a viral genetic polymorphism that independently predicts SVR to PEGIFN/RBV treatment. Kim et al., 2012 suggested the clinical usefulness of the sequence heterogeneity of NS5A in HCV-2a (IRRDR $\geq 4$ ) for determining viral sensitivity to PEG-IFN/RBV therapy. El-Shamy et al., (2012) demonstrated that IRRDR >4, a viral genetic heterogeneity, would be a useful predictive marker for SVR in HCV GT-4 infection when treated with PEG-IFN/RBV.

El shamy et al., (2014) described the importance of the cutoff number of mutations in IRRDR that is associated with treatment outcome that might possibly vary with different geographical regions: In certain geographical regions where $\mathrm{HCV}$ isolates with a high degree of sequence heterogeneity are predominant, a higher cutoff number of IRRDR mutations (such as 6 mutations) is applicable, whereas a lower cutoff number of IRRDR mutations (such as 4 mutations) is better applicable in regions where $\mathrm{HCV}$ isolates with a low degree of sequence heterogeneity are predominant.

$I L-28 B$ host genotype as a host factor considered one of the strongest predictors of peg-IFN/RBV therapy outcome. Two biallelic SNPs rs12979860 (C/T) and rs8099917
(T/G), located upstream of $I L-28 B$ gene may explain differences in the results of the treatment and can be useful as therapy response marker. Previous studies (Rauch $e t$ al., 2010; Suppiah et al., 2009) found that individuals with two copies of the $\mathrm{C}$ allele (CC genotype) for the rs12979860 SNP, were two fold more likely to respond to treatment.

Conversely, individuals carrying the CT or TT genotype were less likely to respond to treatment. Other studies (Rauch et al., 2010; Thomas et al., 2009) demonstrated that two copies of the T allele (TT genotype) for the rs8099917 SNP were strongly associated with natural HCV clearance and SVR. Similar to the rs 12979860 pattern, the rs8099917 TG or GG genotype was less responsive to treatment.

In the present study, the frequency of $I L-28 B$ rs12979860 genotype in our HCV GT-4 Egyptian patients showed that $60 \%$ of them were of the TT genotype, followed by $36.7 \%$ (CT) while CC had the least expression (3.3\%). Previous study found different distribution of $I L 28 B$ genotype. Shaala et al., (2014) revealed that in their GT-4 Egyptian patients, almost half of them were of the CT genotype $(56.7 \%)$ followed by CC (30\%) while TT had the least expression (13\%). As well, Khairy et al., (2013) reported that the frequency of IL28 genotype in their 263 chronic HCV Egyptian patients receiving PEG-IFN/RBV therapy was CT, CC and TT represented $56 \%, 25 \%$ and $19 \%$ of the patients, respectively

In the present study, SVR was achieved in the case with CC genotype of the rs12979860 SNP and in $90.9 \%$ of the CT profile while only achieved in $50 \%$ of those patients with TT genotype. Our results were in agreement with that of Thompson et al., (2010) and De Nicola et al., (2012) who found in their study that in, the CC $I L-28 B$ type was associated 
with improved viral kinetics and greater likelihood of SVR compared with CT and TT.

Regarding the genetic variation in rs8099917, in the present work, $66.7 \%$ of patients with either GT or GG genotype achieved SVR. TT genotype was not displayed in our cases. However the presence of $\mathrm{T}$ allele did not affect the response to treatment. These findings were supported by Antaki et al., (2013) and Hayashi et al., (2015) who found no significant impact of $I L-28 B$ on SVR in their patients concerning rs8099917. In contrast, earlier study stated that rs8099917 is strongly associated with response to PEGIFN/RBV treatment (Akuta et al., 2010; Rosso et al., 2014).

In conclusion, substitutions of core residue either 70 or 91 were related to treatment response in the studied patients with $\mathrm{HCV}$ GT4 infection, this observation needs to be confirmed in studies with larger number of patients with $\mathrm{HCV}-4$ infection taking $I L-28 B$ polymorphisms into consideration. AFP, $I L$ 28 Brs12979860 polymorphism, severity of fibrosis, and NS5A ISDR in particular ISDR $\geq 2$ are useful markers for predicting the outcome of PEG-IFN/RBV therapy for chronic hepatitis C GT-4 and may be used collectively to improve prediction of treatment response.

Hence, the patients who do not achieve sustained virological response need to be identified as early as possible, in order to free them of unnecessary side effects and high costs. Evaluation of the liver to measure the degree of fibrosis as it is considered one of the predicting factors for SVR rates. This could be done either by liver biopsy or better by using the Fibro Scan. Further understanding of the complex interaction between virus- and host-related factors should facilitate the development of more effective therapeutic regimens.

\section{References}

Akuta N, Suzuki F, Hirakawa M, Kawamura Y, Yatsuji H, Sezaki H, et al., 2010 Amino acid substitution in hepatitis $\mathrm{C}$ virus core region and genetic variation near the interleukin 28B gene predict viral response to telaprevir with peginterferon and ribavirin. Hepatology, 52(2):421-429.

Antaki N, Bibert S, Kebbewar K, Asaad F, Baroudi O, Alideeb S, et al., 2013 IL$28 B$ polymorphisms predict response to therapy among chronic hepatitis $\mathrm{C}$ patients with HCV genotype 4. J Viral Hepat, 20(1):59-64.

Asselah T, Bieche I, Narguet S, Sabbagh A, Laurendeau I, Ripault MP, et al., 2008 Liver gene expression signature to predict response to pegylated interferon plus ribavirin combination therapy in patients with chronic hepatitis C. Gut, 57(4):516-24.

Asselah T, Marcellin P. 2011 New directacting antivirals' combination for the treatment of chronic hepatitis C. Liver Int.;31 Suppl 1:68-77.

Bronowicki J-P, Pol S, Thuluvath P, Larrey D, Martorell C, Rustgi V, et al., 2012 1096 Asunaprevir (ASV; BMS650032), an NS3 protease inhibitor, in combination with peginterferon and ribavirin in treatment-naive patients with genotype 1 chronic hepatitis $\mathrm{C}$ infection. J Hepatol, 56:S431-S2.

Cai Q, Zhao Z, Liu Y, Shao X, Gao Z. 2013 Comparison of three different $\mathrm{HCV}$ genotyping methods: core, NS5B sequence analysis and line probe assay. Int J Mol Med, 31(2):347-352.

Darwish NM, Abbas MO, Abdelfattah FM, Darwish MA. 1992 Hepatitis C virus infection in blood donors in Egypt. $\mathrm{J}$ Egypt Public Health Assoc, 67(34):223-236. 
De Nicola S, Aghemo A, Rumi MG, Galmozzi E, Valenti L, Soffredini R, et al., 2012 Interleukin 28B polymorphism predicts pegylated interferon plus ribavirin treatment outcome in chronic hepatitis C genotype 4. Hepatology, 55(2):336-342.

Domagalski K, Pawlowska M, Tretyn A, Halota W, Tyczyno M, Kozielewicz D, et al., 2013 Association of $I L-28 B$ polymorphisms with the response to peginterferon plus ribavirin combined therapy in Polish patients infected with $\mathrm{HCV}$ genotype 1 and 4. Hepat Mon.;13(11):e13678.

El-Shamy A, Shoji I, Saito T, Watanabe H, Ide YH, Deng L, et al., 2011 Sequence heterogeneity of NS5A and core proteins of hepatitis $\mathrm{C}$ virus and virological responses to pegylatedinterferon/ribavirin combination therapy. Microbiol Immunol., 55(6):418-426.

El-Shamy A, Shoji I, El-Akel W, Bilasy SE, Deng L, El-Raziky M, et al., 2012 NS5A sequence heterogeneity of hepatitis $\mathrm{C}$ virus genotype $4 \mathrm{a}$ predicts clinical outcome of pegylatedinterferon-ribavirin therapy in Egyptian patients. J Clin Microbiol., 50(12):3886-92.

El-Shamy A, Hotta H. 2014 Impact of hepatitis $\mathrm{C}$ virus heterogeneity on interferon sensitivity: an overview. World J Gastroenterol, 20(24):75557569.

Enomoto N, Maekawa S. 2010 HCV genetic elements determining the early response to peginterferon and ribavirin therapy. Intervirology, 53(1):66-69.

European Association for Study of Liver. 2015 EASL Recommendations on Treatment of Hepatitis C. J Hepatol. 2015;63(1):199-236.

Fallows G, Kaita K, Minuk G, Penner F, Smart G, Dawood M, et al., 2000 Early changes in hepatitis $\mathrm{C}$ virus (HCV) RNA levels predict response to interferon treatment in noncirrhotic HCV patients. Can J Gastroenterol 14 Suppl B:30B-35B.

Fusco DN, Chung RT. 2011 New protease inhibitors for HCV-help is on the way. J Hepatol.54(6):1087-1089.

Gale MJ, Jr., Korth MJ, Katze MG. 1998 Repression of the PKR protein kinase by the hepatitis $\mathrm{C}$ virus NS5A protein: a potential mechanism of interferon resistance. Clin Diagn Virol 10(23):157-162.

Hayashi K, Katano Y, Ishigami M, Itoh A, Hirooka Y, Nakano I, et al., 2011 Mutations in the core and NS5A region of hepatitis $\mathrm{C}$ virus genotype $1 \mathrm{~b}$ and correlation with response to pegylatedinterferon-alpha $2 \mathrm{~b}$ and ribavirin combination therapy. J Viral Hepat 18(4):280-286.

Hayashi K, Katano Y, Ishizu Y, Kuzuya T, Honda T, Ishigami M, et al., 2015 Association of interleukin 28B polymorphism and mutations in the NS5A region of hepatitis $\mathrm{C}$ virus genotype 2 with interferon responsiveness. J Gastroenterol Hepatol 30(1):178-183.

Itakura J, Kurosaki M, Takada H, Nakakuki N, Matsuda S, Gondou K, et al., 2015 Naturally occurring, resistanceassociated hepatitis $\mathrm{C}$ virus NS5A variants are linked to IL-28B genotype and are sensitive to interferon-based therapy. Hepatol Res. 45(10):E115-121

Kau A, Vermehren J, Sarrazin C. 2008 Treatment predictors of a sustained virologic response in hepatitis $\mathrm{B}$ and $\mathrm{C}$. J Hepatol. 49(4):634-651.

Khairy M, Fouad R, Mabrouk M, El-Akel W, Awad AB, Salama R, et al., 2013 The impact of interleukin 28b gene polymorphism on the virological response to combined pegylated 
interferon and ribavirin therapy in chronic HCV genotype 4 infected egyptian patients using data mining analysis. Hepat Mon. 13(7)

Kim SR, El-Shamy A, Imoto S, Kim KI, Ide Y-h, Deng L, et al., 2012 Prediction of response to pegylated interferon/ribavirin combination therapy for chronic hepatitis $\mathrm{C}$ genotype $1 \mathrm{~b}$ and high viral load. J Gastroenterol. 47(10):1143-1151.

Lavanchy D. 2011 Evolving epidemiology of hepatitis $\mathrm{C}$ virus. Clin Microbiol Infect. 17(2):107-115.

Magrin S, Craxi A, Fabiano C, Marino L, Fiorentino G, Iacono OL, et al., 1996 $\mathrm{HCV}$ viraemia is more important than genotype as a predictor of response to interferon in Sicily (Southern Italy). J Hepatol. 25(5):583-590.

Miller FD, Abu-Raddad LJ. 2010 Evidence of intense ongoing endemic transmission of hepatitis C virus in Egypt. Proc Natl Acad Sci USA. 107(33):14757-14762.

Nakagawa M, Sakamoto N, Ueyama M, Mogushi K, Nagaie S, Itsui Y, et al., 2010 Mutations in the interferon sensitivity determining region and virological response to combination therapy with pegylated-interferon alpha $2 \mathrm{~b}$ plus ribavirin in patients with chronic hepatitis $\mathrm{C}-1 \mathrm{~b}$ infection. J Gastroenterol 45(6):656-665.

Nguyen LT, Gray E, Dean J, Carr M, Connell J, De Gascun C, et al., 2015 Baseline prevalence and emergence of protease inhibitor resistance mutations following treatment in chronic $\mathrm{HCV}$ genotype 1infected individuals. Antivir Ther. 20(8):865-869

Okanoue T, Itoh Y, Hashimoto H, Yasui K, Minami M, Takehara T, et al., 2009 Predictive values of amino acid sequences of the core and NS5A regions in antiviral therapy for hepatitis
C: a Japanese multi-center study. J Gastroenterol 44(9):952-963.

Polyak SJ, Khabar KS, Paschal DM, Ezelle HJ, Duverlie G, Barber GN, et al., 2001 Hepatitis C virus nonstructural 5A protein induces interleukin-8, leading to partial inhibition of the interferoninduced antiviral response. J Virol 75(13):6095-6106.

Powis J, Peltekian K, Lee S, Sherman M, Bain V, Cooper C, et al., 2008 Exploring differences in response to treatment with peginterferon alpha $2 \mathrm{a}$ $(40 \mathrm{kD})$ and ribavirin in chronic hepatitis $\mathrm{C}$ between genotypes 2 and 3. J Viral Hepat 15(1):52-57.

Rauch A, Kutalik Z, Descombes P, Cai T, Di Iulio J, Mueller T, et al., 2010 Genetic variation in $I L-28 B$ is associated with chronic hepatitis $\mathrm{C}$ and treatment failure: a genome-wide association study. Gastroenterology. 138(4):13381345.

Rosso C, Abate ML, Ciancio A, Strona S, Caviglia GP, Olivero A, et al., 2014 IL$28 B$ polymorphism genotyping as predictor of rapid virologic response during interferon plus ribavirin treatment in hepatitis $\mathrm{C}$ virus genotype 1 patients. World J Gastroenterol. 20(36):13146-13152.

Shaala AY, Morsi MG, Harfoush RAH, ElKhouly EH, Ahmed MAR, Roshdy MN. 2015 Role of IL-28B polymorphisms in virologic response to combined pegylated interferon and ribavirin therapy in genotype 4 chronic $\mathrm{HCV}$ infected patients with and without cirrhosis. Alexandria Journal of Medicine. 51(3):231-239

Shirakawa H, Matsumoto A, Joshita S, Komatsu M, Tanaka N, Umemura T, et al., 2008 Pretreatment prediction of virological response to peginterferon plus ribavirin therapy in chronic 
hepatitis $\mathrm{C}$ patients using viral and host factors. Hepatology. 48(6):1753-1760.

Smith DB, Bukh J, Kuiken C, Muerhoff AS, Rice CM, Stapleton JT, et al., 2014 Expanded classification of hepatitis $\mathrm{C}$ virus into 7 genotypes and 67 subtypes: updated criteria and genotype assignment web resource. Hepatology 59:318-327.

Suppiah V, Moldovan M, Ahlenstiel G, Berg T, Weltman M, Abate ML, et al., 2009 $I L-28 B$ is associated with response to chronic hepatitis $\mathrm{C}$ interferon- $\alpha$ and ribavirin therapy. Nat Genet. 41(10):1100-1104.

Suzuki F, Sezaki H, Akuta N, Suzuki Y, Seko Y, Kawamura Y, et al., 2012 Prevalence of hepatitis $C$ virus variants resistant to NS3 protease inhibitors or the NS5A inhibitor (BMS-790052) in hepatitis patients with genotype 1b. J Clin Virol. 54(4):352-354.
Thomas DL, Thio CL, Martin MP, Qi Y, Ge D, O'hUigin C, et al., 2009 Genetic variation in $I L-28 B$ and spontaneous clearance of hepatitis $C$ virus. Nature 461(7265):798-801

Thompson AJ, Muir AJ, Sulkowski MS, Ge D, Fellay J, Shianna KV, et al., 2010 Interleukin-28B polymorphism improves viral kinetics and is the strongest pretreatment predictor of sustained virologic response in genotype 1 hepatitis $\mathrm{C}$ virus. Gastroenterology 139(1):120-129.

Zein NN, Rakela J, Krawitt EL, Reddy KR, Tominaga T, Persing DH. 1996 Hepatitis C virus genotypes in the United States: epidemiology, pathogenicity, and response to interferon therapy. Collaborative Study Group. Ann Intern Med 125(8):634639.

\section{How to cite this article:}

Ghada Fahmy Helaly, Amel Gaber Elsheredy, Essam El Din Saeed Bedewy and Nancy Mohamed Attia. 2017. Sequence Heterogeneity in the core and NS5A region of hepatitis C virus (HCV) and IL-28B Polymorphisms in Predicting Treatment Response among Chronic HCV Genotype 4 Infected Egyptian Patients. Int.J.Curr.Microbiol.App.Sci. 6(7): 2382-2398. doi: https://doi.org/10.20546/ijcmas.2017.607.282 